\title{
KOMPETENSI NAKHODA KAPAL RAWAI TUNA DI PALABUHANRATU DITINJAU DARI STANDAR KOMPETENSI KERJA NASIONAL INDONESIA (SKKNI)
}

\author{
Competency of Tuna Longliner Captain at Palabuhanratu, Viewed From Indonesian \\ National Working Competency Standards (SKKNI)
}

Oleh:

Tri Wiji Nurani ${ }^{1 *}$, Yasinta Anugerah ${ }^{2}$, Muhammad Fedi A. Sondita ${ }^{1}$

\author{
${ }^{1}$ Departemen Pemanfaatan Sumberdaya Perikanan, Fakultas Perikanan dan Ilmu Kelautan, Institut Pertanian Bogor \\ 2 Program Studi Teknologi Perikanan Laut, Sekolah Pascasarjana, Institut Pertanian Bogor \\ ${ }^{*}$ Korespondensi: triwiji@hotmail.com
}

Diterima: 12 April 2016; Disetujui: 14 September 2016

\begin{abstract}
Indonesian government has prepared a standard for assessing the competencies of human resources in the field of fisheries, through the formulation of Indonesian National Occupational Competency Standards (INOCS). Captain of fishing vessels has an important role to the success of fishing operations, which must be supported by adequate competencies. This research aimed to describe INOCS in the field of fishing; and to assess the competence of the Captain of longline fishing vessels according to the INOCS. Data analysis was carried out by descriptive and gap analysis method. The result of the study showed that the competency of the Captain had been formulated, included five units of competencies with twenty elements of competencies. Among them, ten elements of competencies had been achieved, while the other ten competencies still had gaps. Elements of competency that has been achieved are mostly in accordance with the level $\mathrm{V}$, while the level VI had not been achieved yet.
\end{abstract}

Keywords: captain, competency, gap analysis, SKKNI, tuna longline

\begin{abstract}
ABSTRAK
Pemerintah Indonesia telah mempersiapkan perangkat untuk menilai kompetensi sumberdaya manusia di bidang perikanan, melalui perumusan Standar Kompetensi Kerja Nasional Indonesia (SKKNI). Nakhoda kapal penangkap ikan tuna memiliki peran penting untuk keberhasilan operasi penangkapan ikan, yang harus didukung oleh kompetensi yang memadai. Penelitian ini bertujuan untuk mempelajari SKKNI di bidang penangkapan ikan; dan menilai kompetensi Nakhoda sesuai SKKNI. Analisis dilakukan secara deskriptif dengan menggunakan analisis kesenjangan (gap). Hasil penelitian menyatakan bahwa unit kompetensi nakhoda telah dirumuskan dengan baik. Terdapat lima unit kompetensi dengan dua puluh elemen kompetensi. Sepuluh elemen kompetensi telah tercapai, sementara itu sepuluh elemen kompetensi lainnya masih terdapat gap. Elemen kompetensi yang sudah tercapai sebagian besar adalah sesuai dengan jenjang V, sementara itu yang belum tercapai pada jenjang VI.
\end{abstract}

Kata kunci: nakhoda, kompetensi, analisis kesenjangan, SKKNI, tuna longline 


\section{PENDAHULUAN}

Masyarakat Ekonomi Asean (MEA) atau Asean Single Economic Community (AEC) dimulai akhir tahun 2015. Saat MEA diberlakukan, maka aliran barang, jasa, investasi termasuk tenaga kerja akan bergerak bebas. Persaingan terbuka untuk dua belas sektor prioritas, termasuk sektor perikanan. Beberapa negara di kawasan ASEAN, seperti Malaysia, Philipina, Singapore, Thailand, Vietnam telah menyiapkan berbagai strategi menghadapi MEA.

Indonesia memiliki potensi di sektor perikanan laut yang sangat besar. Indonesia merupakan negara kepulauan dengan luas lautan sekitar 5,8 juta $\mathrm{km}^{2}$. Wilayah laut Indonesia memiliki potensi sumberdaya ikan yang diperkirakan sekitar 6,6 juta ton per tahun. Jumlah nelayan sebagai sumberdaya manusia yang bergerak langsung di sektor perikanan diperkirakan sekitar 3,7 juta. Indonesia harus mempersiapkan strategi untuk dapat memproteksi sumberdaya alam dan sumberdaya manusia dengan diberlakukannya MEA.

Keunggulan komparatif Indonesia jika dibandingkan dengan negara lain di kawasan ASEAN dalam hal kepemilikan sumberdaya alam, harus diiringi dengan keungulan kompetitif dari sumberdaya manusianya. Pemberlakuan MEA, akan mengakibatkan arus tenaga kerja atau sumberdaya manusia (SDM) terampil dan profesional dari negara-negara ASEAN akan bebas masuk ke Indonesia. Pemantapan kompetensi SDM bidang perikanan dan kelautan menjadi satu hal yang perlu untuk dilakukan agar dapat bersaing dengan tenaga kerja dari negara ASEAN lainnya.

Pemerintah Indonesia telah menetapkan Peraturan Presiden No 8/2012 tentang Kerangka Kualifikasi Nasional Indonesia (KKNI). KKNI adalah kerangka penjenjangan kualifikasi kompetensi yang dapat menyandingkan, menyetarakan, dan mengintegrasikan antara bidang pendidikan dan bidang pelatihan kerja serta pengalaman kerja dalam rangka pemberian pengakuan kompetensi kerja sesuai dengan struktur pekerjaan di berbagai sektor. Sesuai dengan kualifikasi yang ada dalam KKNI, kebutuhan SDM perikanan dan kelautan mencakup berbagai jenjang kualifikasi, dari kualifikasi operator, teknisi/analis hingga kualifikasi ahli.

Kondisi saat ini SDM perikanan dan kelautan, seperti misalnya nelayan sebagai pelaku utama di bidang perikanan tangkap memiliki kompetensi yang belum terstandar. Sebagian besar nelayan memiliki kompetensi sebagai nelayan berdasarkan pengetahuan dan keterampilan yang diperoleh secara turun temurun.
Baru sebagian kecil nelayan yang memiliki sertifikat, yang merupakan persyaratan yang diwajibkan seperti sertifikat untuk Nakhoda kapal.

Mengacu pada konvensi FAO yaitu Code of Conduct For Responsible Fisheries (CCRF) tahun 1995, terdapat ketentuan yang menjelaskan pentingnya tanggung jawab terhadap keselamatan nelayan dan kapal ikan. Pada Bab 8 dinyatakan, setiap negara harus memastikan standar kesehatan dan keselamatan untuk semua orang yang bekerja pada operasi penangkapan telah diterapkan. Standar tersebut harus tidak kurang dari persyaratan minimum dari perjanjian internasional yang relevan dengan kondisi pekerjaan dan pelayanan bagi pekerja (Purwangka et al. 2013).

Berdasarkan hal tersebut di atas, timbul satu pertanyaan "Siapkah SDM Perikanan Indonesia, khususnya nelayan bersaing dalam kerangka MEA? Kesiapan SDM Perikanan perlu dilakukan melalui kualifikasi dan kompetensi yang terstandar. Pemerintah sudah mempersiapkan perangkat untuk menilai kompetensi SDM di bidang perikanan melalui perumusan Standar Kompetensi Kerja Nasional Indonesia (SKKNI). Penelitian ini dilakukan, dengan tujuan: 1) Mendeskripsikan SKKNI di bidang penangkapan ikan; 2) Menilai kompetensi SDM Perikanan sesuai SKKNI.

Penilaian dilakukan melalui studi kasus pada nakhoda kapal rawai tuna (longline) di Pelabuhan Perikanan Nusantara (PPN) Palabuhanratu. Nakhoda kapal memiliki peran yang sangat penting untuk keberhasilan operasi penangkapan ikan. Tujuan utama penangkapan ikan dengan longline adalah pasar ekspor. Kualitas hasil tangkapan menjadi hal yang harus diprioritaskan, dan hal ini akan terkait dengan pengetahuan, keahlian dan keterampilan dari nakhoda kapal (Nurani et al. 2012; Nurani et al. 2013). Pemilihan lokasi untuk studi kasus penelitian di PPN Palabuhanratu, dikarenakan lokasi ini merupakan salah satu tempat pendaratan bagi kapal longline (Nurani et al. 2008; Nurani et al. 2010; Ardani et al. 2013).

\section{METODE}

Penelitian dilakukan pada bulan Desember 2014-Februari 2015 di Pelabuhan Perikanan Nusantara (PPN) Palabuhanratu. Data untuk mempelajari Standar Kompetensi Kerja Nasional Indonesia (SKKNI) di bidang penangkapan ikan adalah dengan mempelajari dokumen Lampiran Keputusan Menteri Tenaga Kerja No. 298/2013 tentang Penetapan SKKNI 
Kategori Pertanian, Kehutanan, Perikanan; Golongan Pokok Perikanan; Golongan Penangkapan Ikan; Sub Golongan Penangkapan Ikan di Laut.

Data kompetensi yang dimiliki oleh nelayan diperoleh melalui pengisian daftar pertanyaan (kuesioner) sesuai dengan SKKNI. Selain itu, juga diperoleh melalui observasi langsung kegiatan persiapan sebelum operasi penangkapan dilakukan, serta melihat dokumen-dokumen kapal dan sertifikat yang berkaitan dengan kompetensi. Daftar pertanyaan mencakup kompetensi sesuai SKKNI yang harus dimiliki oleh Nakhoda kapal longline. Jawaban yang diberikan oleh responden dapat memberikan gambaran dan penilaian unit kompetensi yang mereka miliki. Penilaian kompetensi dari jawaban responden terbagi menjadi dua, yaitu YA dan TIDAK. Jawaban YA menggambarkan responden dapat menjawab pertanyaan sesuai unit kompetensi, sedangkan jawaban TIDAK menggambarkan responden tidak tahu atau tidak bisa menjawab pertanyaan sesuai unit kompetensi. Responden meliputi 11 orang nakhoda kapal longline, 2 orang wakil nakhoda, 4 orang bosman, 3 orang KKM, 14 orang $\mathrm{ABK}$ biasa, 1 orang koki dan 1 orang prossesing.

Analisis data meliputi: 1) Analisis deskriptif untuk mempelajari SKKNI di bidang penangkapan ikan; dan 2) Analisis kesenjangan (gap) untuk menilai kompetensi nakhoda kapal rawai tuna (longline) di PPN Palabuhanratu sesuai SKKNI. Kompetensi dinilai dari ada atau tidaknya kesenjangan yang terjadi antara kompetensi standar dan kompetensi aktual (Susilo et al. 2011; Ramadhan 2014).

Analisis kesenjangan dilakukan dengan menilai langsung kompetensi nakhoda di lapangan dengan menggunakan skala dikotomi (0 : Tidak dan 1 : Ya). Kesenjangan kompetensi adalah perbedaan antara level kompetensi yang diperlukan pada suatu posisi dan level kompetensi saat ini. Nilai gap menunjukan bahwa responden belum memiliki kompetensi sesuai dengan standar. Sedangkan nilai gap 0 menunjukan responden telah memiliki kompetensi sesuai dengan standar yang ada. Menurut Palan (2007) kesenjangan dihitung dengan rumus:

$$
\begin{aligned}
& \text { Kesenjangan }(\text { Gap })=\left(C L_{R}-C L_{C}\right) \ldots \ldots \ldots . \\
& \text { Kompetensi Tercapai }=\left(\Sigma C L_{C}\right) /\left(\Sigma C L_{R}\right) \times 100 \% .
\end{aligned}
$$

Dengan:

Current Competency Level $\left(\mathrm{CL}_{C}\right)$ : Kompetensi saat ini ; ū1 $+\bar{u} 2+\ldots+$ ūi dimana $i$ adalah unit kompetensi ke $i$ dari nahkoda atau $A B K$

Required Competency Level $\left(\mathrm{CL}_{\mathrm{R}}\right)$ : Nilai kompetensi maksimum yang diperlukan.

\section{HASIL}

Standar Kompetensi Kerja Nasional Indonesia (SKKNI) Bidang Penangkapan Ikan telah ditetapkan dalam Lampiran Keputusan Menteri Tenaga Kerja No. 298/2013 tentang Penetapan SKKNI Kategori Pertanian, Kehutanan, Perikanan; Golongan Pokok Perikanan; Golongan Penangkapan Ikan; Sub Golongan Penangkapan Ikan di Laut. Dalam lampiran ini disebutkan bahwa SKKNI merupakan uraian kemampuan yang mencakup pengetahuan, keterampilan dan sikap kerja minimal yang harus dimiliki seseorang untuk menduduki jabatan tertentu yang berlaku secara nasional. SKKNI untuk profesi di bidang penangkapan ikan telah ditetapkan dalam lampiran keputusan ini.

Bab II SKKNI, mencakup A. Peta Kompetensi, B. Pemetaan dan Kemasan Standar Kompetensi, C. Daftar Unit Kompetensi dan D. Pemetaan Berdasarkan Jabatan/Okupasi. Mengacu pada Peta Kompetensi, maka SKKNI profesi di bidang penangkapan ikan memiliki tujuan utama yaitu "Melakukan penangkapan ikan di laut dengan cara baik dan bertanggungjawab untuk kegiatan komersial yang ramah lingkungan dan berkelanjutan untuk menghasilkan ikan yang bermutu dan sesuai kebutuhan pasar". Nakhoda memiliki dua fungsi kunci yaitu "Melakukan penangkapan ikan di laut" dan "Melakukan proses penangkapan ikan". Fungsi kunci pertama "Melakukan penangkapan ikan di laut", memiliki fungsi utama yaitu: 1) Melakukan persiapan berlayar di pelabuhan, dan 2) Melaksanakan pelayaran menuju dan dari daerah penangkapan ikan; dengan fungsi dasar meliputi: 1) Merencanakan operasi penangkapan ikan, 2) Menyiapkan kelaiklautan kapal, 3) Menyiapkan kelaikan operasi penangkapan ikan, dan 4) Melaksanakan tugas jaga laut (watchkeeping). Fungsi kunci yang kedua yaitu: Melakukan proses penangkapan ikan, dengan fungsi utama "Melakukan penangkapan ikan dengan menggunakan alat penangkap ikan berbahan utama tali dan pancing", serta fungsi dasar "Melakukan penangkapan ikan di laut dengan menggunakan rawai tuna (tuna longline)".

Pada Pemetaan dan Kemasan Standar Kompetensi sesuai dengan KKNI, telah dirumuskan jenjang kualifikasi dan unit kompetensi untuk profesi di bidang perikanan dari jenjang kualifikasi VI, V, dan III. Berdasarkan pemahaman terhadap profesi nakhoda kapal longline yang ada di PPN Palabuhanratu, unit kompetensi yang berkaitan dengan profesi 
nakhoda berada pada Jenjang VI (Tabel 1). Jenjang $\mathrm{V}$ (Tabel 2) adalah jenjang untuk Perwira Kapal. Pada penelitian ini, nakhoda kapal longline penangkap ikan yang ada di PPN Palabuhanratu, juga melakukan pekerjaan yang ada pada jenjang $\mathrm{V}$ ini.

Lampiran Keputusan Menteri Tenaga Kerja No. 298/2013, menjabarkan "Unit Kompetensi" ke dalam elemen kompetensi dan kriteria unjuk kerja. Unit kompetensi "Merencanakan Operasi Penangkapan Ikan" memiliki deskripsi yaitu unit ini berhubungan dengan pengetahuan, keterampilan dan sikap kerja yang dibutuhkan dalam melakukan perencanaan operasi penangkapan ikan. Elemenelemen yang tercakup dalam unit kompetensi "Merencanakan Operasi Penangkapan Ikan" dan kriteria unjuk kerjanya disampaikan pada Tabel 3.

Unit kompetensi "Menyiapkan kelaiklautan kapal (seaworthiness of ship)" memiliki deskripsi yaitu unit ini berhubungan dengan pengetahuan, keterampilan dan sikap kerja yang dibutuhkan dalam menyiapkan kelaiklautan kapal. Elemen-elemen yang tercakup dalam unit kompetensi "Menyiapkan kelaiklautan kapal (seaworthiness of ship)" dan kriteria unjuk kerjanya seperti terlihat pada Tabel 4.

Unit kompetensi "Menyiapkan kelaikan operasi penangkapan ikan (fishing operation worthiness)" memiliki deskripsi yaitu, unit ini berhubungan dengan pengetahuan, keterampilan dan sikap kerja yang dibutuhkan dalam menyiapkan kelaikan operasi penangkapan ikan. Elemen-elemen yang tercakup dalam unit kompetensi "Menyiapkan kelaikan operasi penangkapan ikan (fishing operation worthiness)" dan kriteria unjuk kerjanya seperti terlihat pada Tabel 5.

Unit kompetensi "Melaksanakan tugas jaga laut (watchkeeping)" memiliki deskripsi yaitu, unit ini berhubungan dengan pengetahuan, keterampilan dan sikap kerja yang dibutuhkan dalam melaksanakan tugas jaga laut (watchkeeping). Elemen-elemen yang tercakup dalam unit kompetensi "Melaksanakan tugas jaga laut (watchkeeping)" dan kriteria unjuk kerjanya seperti terlihat pada Tabel 6 .

Unit kompetensi "Melakukan penangkapan ikan di laut dengan menggunakan rawai tuna (long line)" memiliki deskripsi yaitu, unit ini berhubungan dengan pengetahuan, keterampilan dan sikap kerja yang dibutuhkan dalam melakukan penangkapan ikan di laut dengan menggunakan rawai tuna (long line). Elemenelemen yang tercakup dalam unit kompetensi "Melakukan penangkapan ikan di laut dengan menggunakan rawai tuna (longline)" dan kriteria unjuk kerjanya seperti terlihat pada Tabel 7.

Hasil penelitian menyatakan masih adanya kesenjangan (gap) kompetensi nakhoda kapal longline dengan SKKNI (Tabel 8). Kompetensi nahkoda mencakup 5 unit kompetensi dengan 20 elemen kompetensi. Nakhoda kapal longline telah memenuhi $100 \%$ pada 10 elemen kompetensi, sementara 10 elemen kompetensi lainnya masih ada kesenjangan (gap). Nilai kesenjangan terendah terjadi pada elemen "Menghitung waktu operasi dan kebutuhan operasi penangkapan ikan" dengan nilai gap 0,02 . Adapun nilai gap tertinggi pada elemen "Melengkapi dokumen kapal" dengan nilai gap 0,92 .

Tabel 9 berisikan capaian kompetensi yang telah dipenuhi oleh Nakhoda kapal longline yang ada di PPN Palabuhanratu. Nilai persentase yang mendekati $100 \%$ dapat diartikan memiliki kompetensi yang telah memenuhi standar. Unit "Melakukan penangkapan ikan di laut dengan menggunakan rawai tuna "memiliki nilai persentase tertinggi yaitu $90 \%$. Unit kompetensi yang terendah adalah unit "Menyiapkan kelaiklautan kapal" dengan persentase $59 \%$ dan unit "Menyiapkan kelaikan operasi penangkapan ikan" memiliki nilai $66 \%$. Hal ini dapat dinyatakan bahwa nakhoda kapal longline di PPN Palabuhanratu lebih menguasai kompetensi pada jenjang $V$ atau Perwira Kapal dari pada jenjang VI atau nakhoda kapal penangkap ikan.

\section{PEMBAHASAN}

Standar Kompetensi Kerja Nasional Indonesia telah memberikan arahan yang jelas bagi SDM atau nelayan yang bekerja di bidang penangkapan ikan, yaitu melakukan penangkapan ikan di laut dengan cara baik dan bertanggungjawab untuk kegiatan komersial yang ramah lingkungan dan berkelanjutan untuk menghasilkan ikan yang bermutu dan sesuai kebutuhan pasar. Tidak semua nelayan longline memahami hal ini. Sebagian besar nelayan berpendidikan rendah, dalam penelitian ini $66 \%$ nelayan longline berpendidikan SD. Nurani et al. (2012) menyatakan bahwa implementasi manajemen mutu di kapal perikanan di PPN Palabuhanratu, termasuk kapal longline masih rendah disebabkan rendahnya pemahaman nelayan akan sanitasi dan hiegene dalam penanganan ikan. Hal ini juga didukung hasil penelitian Iskandar et al. (2011) yang menyatakan, hal yang sangat dipengaruhi oleh kompetensi ABK adalah sanitasi dan kesehatan pekerja. Kesehatan dan kebersihan ABK pada saat penanganan ikan tuna di atas kapal belum memenuhi standar. Hal ini juga terlihat dari dari 
Tabel 1 Unit kompetensi golongan pokok pertanian; nama pekerjaan/profesi nakhoda kapal penangkapan ikan; jenjang KKNI sertifikat VI

\begin{tabular}{lll}
\hline $\begin{array}{c}\text { No. } \\
\text { kode }\end{array}$ & Kode unit & \multicolumn{1}{c}{ Judul unit kompetensi } \\
\hline 1. & A.031110.001.01 & Merencanakan operasi penangkapan ikan \\
2. & A.031110.002.01 & Menyiapkan kelaiklautan kapal \\
3. & A.031110.003.01 & Menyiapkan kelaikan operasi penangkapan ikan \\
\hline
\end{tabular}

Tabel 2 Unit kompetensi golongan pokok pertanian; nama pekerjaan/profesi perwira kapal penangkapan ikan; jenjang KKNI Sertifikat V

\begin{tabular}{ccc}
\hline $\begin{array}{c}\text { No. } \\
\text { kode }\end{array}$ & Kode unit & \multicolumn{1}{c}{ Judul unit kompetensi } \\
\hline 1. & A.031110.004.01 & $\begin{array}{l}\text { Melaksanakan tugas jaga laut } \\
\text { Melakukan penangkapan ikan di laut dengan menggunakan rawai } \\
\text { tuna (tuna long line) }\end{array}$ \\
\hline 2. & A.031110.013.01 & \\
\hline
\end{tabular}

Tabel 3 Elemen kompetensi dan kriteria unjuk kerja dari unit kompetensi merencanakan operasi penangkapan ikan dengan kode unit A.031110.001.01

\begin{tabular}{|c|c|c|c|}
\hline \multicolumn{2}{|r|}{ Elemen kompetensi } & \multicolumn{2}{|r|}{ Kriteria unjuk kerja } \\
\hline \multirow[t]{3}{*}{1.} & $\begin{array}{l}\text { Menentukan jenis ikan } \\
\text { sasaran, alat penangkapan } \\
\text { ikan dan daerah }\end{array}$ & 1.1 & $\begin{array}{l}\text { Alat penangkapan ikan, jenis ikan sasaran penangkapan ikan, } \\
\text { gross tonnage kapal dan daerah penangkapan ikan yang sesuai } \\
\text { dengan Surat ljin Penangkapan Ikan (SIPI) ditetapkan. }\end{array}$ \\
\hline & penangkapan ikan. & 1.2 & Peta laut penerbitan terbaru disiapkan. \\
\hline & & 1.3 & $\begin{array}{l}\text { Kondisi keamanan kapal, awak kapal dan keamanan pelayaran } \\
\text { sesuai daerah penangkapan ikan diidentifikasi. }\end{array}$ \\
\hline \multirow[t]{2}{*}{2.} & Memprakirakan cuaca. & 2.1 & Kondisi cuaca di daerah penangkapan ikan diidentifikasi. \\
\hline & & 2.2 & $\begin{array}{l}\text { Pengaruh cuaca terhadap keamanan stabilitas kapal dan } \\
\text { operasi penangkapan ikan dihitung. }\end{array}$ \\
\hline \multirow[t]{5}{*}{3.} & Menghitung waktu operasi & 3.1 & Peta laut dan peralatan menjangka peta disiapkan. \\
\hline & dan kebutuhan operasi. & 3.2 & $\begin{array}{l}\text { Rute pelayaran dari fishing base ke fishing ground dan dari } \\
\text { fishing base ke tempat pendaratan ikan ditentukan. }\end{array}$ \\
\hline & & 3.3 & $\begin{array}{l}\text { Waktu dan jarak tempuh antara fishing base dan fishing ground } \\
\text { pergi pulang di peta laut diukur. }\end{array}$ \\
\hline & & 3.4 & Estimasi waktu operasi penangkapan ikan dihitung. \\
\hline & & 3.5 & $\begin{array}{l}\text { Estimasi logistic operasional kapal dan logistic crew kapal } \\
\text { dihitung. }\end{array}$ \\
\hline \multirow[t]{2}{*}{4.} & $\begin{array}{l}\text { Mendokumentasikan } \\
\text { rencana operasi } \\
\text { penangkapan ikan. }\end{array}$ & 4.1 & $\begin{array}{l}\text { Waktu dan jarak tempuh pelayaran, operasi penangkapan ikan, } \\
\text { jenis dan estimasi jumlah ikan sasaran, daerah penangkapan } \\
\text { ikan, tempat pendaratan ikan, perkiraan kondisi kapal, awak } \\
\text { kapal, cuaca, rute pelayaran, dan posisi daerah-daerah } \\
\text { berbahaya dan stasiun pantai terdekat yang akan dihubungi jika } \\
\text { terjadi keadaan darurat dicatat. }\end{array}$ \\
\hline & & 4.2 & $\begin{array}{l}\text { Dokumen rencana operasi penangkapan dilaporkan kepada } \\
\text { pejabat yang berwenang (antara lain perusahaan dan } \\
\text { syahbandar). }\end{array}$ \\
\hline
\end{tabular}

Tabel 4 Elemen kompetensi dan kriteria unjuk kerja dari unit kompetensi menyiapkan kelaiklautan kapal (seaworthiness of ship) dengan kode unit A.031110.002.01

\begin{tabular}{lll}
\hline \multicolumn{1}{l}{ Elemen kompetensi } & \multicolumn{1}{c}{ Kriteria unjuk kerja } \\
\hline 1. $\begin{array}{l}\text { Melengkapi dokumen } \\
\text { kapal }\end{array}$ & 1.1 Dokumen kapal sesuai dengan peraturan yang ditetapkan oleh \\
instansi terkait disiapkan
\end{tabular}


Tabel 4 Elemen kompetensi dan kriteria unjuk kerja dari unit kompetensi menyiapkan kelaiklautan kapal (seaworthiness of ship) dengan kode unit A.031110.002.01 (Lanjutan)

Elemen kompetensi

4. Melaporkan

keberangkatan kapal ke syahbandar perikanan dan syahbandar umum

\section{Kriteria unjuk kerja}

4.1 Dokumen-dokumen kelaikan operasi penangkapan ikan dilaporkan ke pengawas perikanan untuk mendapatkan surat laik operasi, (SLO) penangkapan ikan

4.2 Dokumen-dokumen kelaiklautan kapal dilaporkan ke syahbandar di pelabuhan perikanan atau syahbandar umum untuk mendapatkan surat persetujuan berlayar

Tabel 5 Elemen kompetensi dan kriteria unjuk kerja dari unit kompetensi menyiapkan kelaikan operasi penangkapan ikan dengan kode unit A.031110.003.01

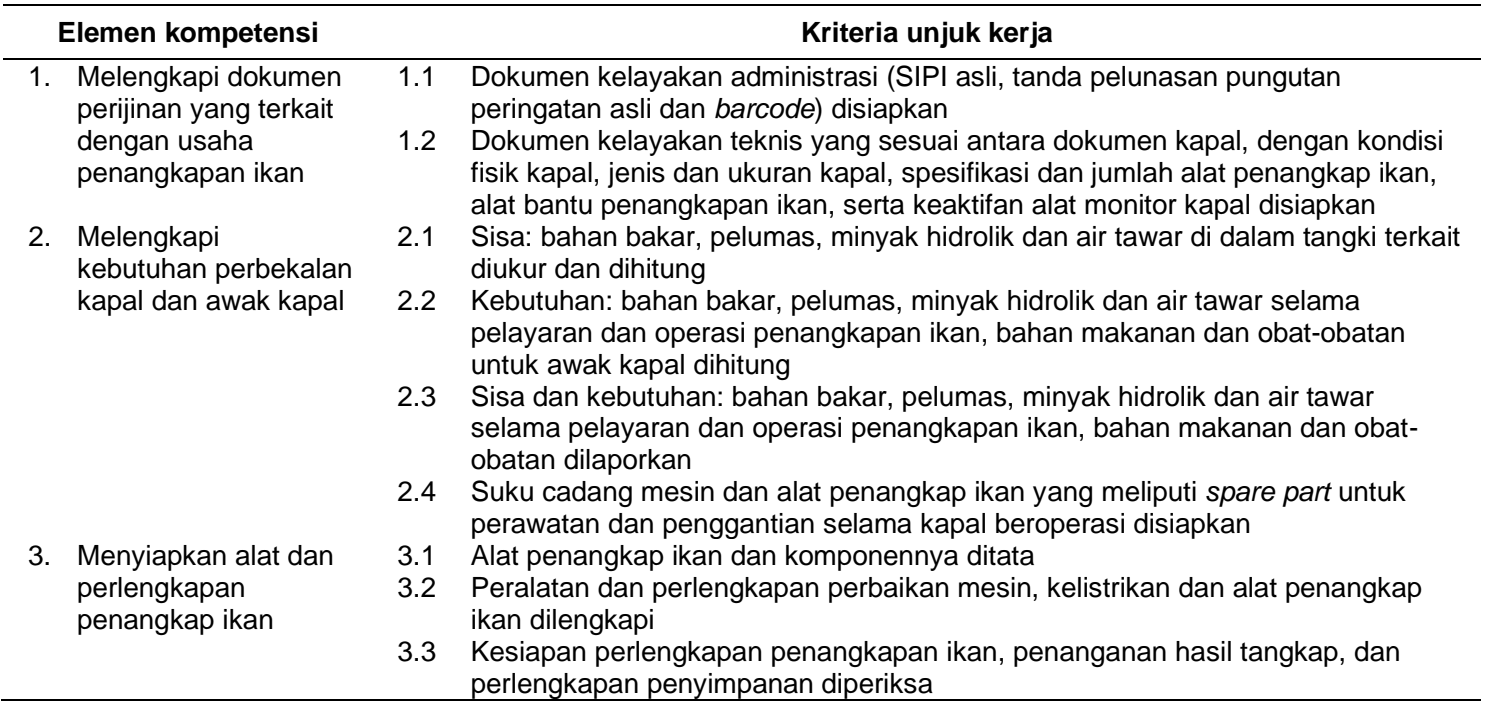

Tabel 6 Elemen kompetensi dan kriteria unjuk kerja dari unit kompetensi melaksanakan tugas jaga laut dengan kode unit A.031110.004.01

Elemen kompetensi

1. Menyiapkan perlengkapan dinas jaga laut

2. Memantau rute, pengendalian kapal, dan keamanan berlayar

\section{Kriteria unjuk kerja}

Peta laut, peralatan menjangka peta, dan buku-buku publikasi navigasi sesuai rute pelayaran disiapkan di meja peta

1.2 Perairan-perairan berbahaya di peta laut yang sedang digunakan ditandai sesuai ketentuan Peta Laut Indonesia Nomor. 1

2.1 Ketentuan-ketentuan terkait dengan peraturan internasional untuk mencegah tubrukan di laut diterapkan

2.2 Perbaikan posisi, haluan, kecepatan kapal dilakukan

2.3 Berbagai perbaikan posisi, haluan, kecepatan kapal dicatat di dalam buku harian dek

2.4 Pengamatan keliling yang baik (look out) dilaksanakan selama dinas jaga sesuai COLREG tahun 1972

2.5 Kondisi atau situasi yang menyebabkan akan terjadinya resiko tubrukan, kandas, dan bahaya navigasi lainnya diidentifikasi dan dicatat

2.6 Jarak tampak, keadaan cuaca dan laut diidentifikasi dan dicatat

2.7 Kepadatan lalu lintas dan aktivitas lain dimana kapal sedang berlayar diidentifikasi

2.8 Kemampuan operasional seluruh peralatan navigasi diuji secara berkala sedikitnya sekali setiap putaran tugas jaga laut

2.9 Kemampuan operasional instrument dan alat pengendali di anjungan, termasuk sistem tanda bahaya diuji

2.10 Kemudi otomatis sesuai trek pelayaran dikontro

2.11 Orang yang menjalankan kemudi manual mengikuti trek pelayaran dikontrol

2.12 Deviasi pada kompas standar sedikitnya sekali setiap putaran dinas jaga laut dicek sesuai daftar deviasi

2.13 Penunjukan haluan Kompas Induk dan semua repeteamya disinkronkan

2.14 Kondisi kapal yang menyebabkan adanya perubahan perubahan stabilitas kapal diidentifikasi

2.15 Tindakan-tindakan berdasarkan pesan penting dari petugas jaga laut sebelumnya atau perintah nakhoda dilaksanakan

2.16 Buku harian dek diisi

2.17 Serah terima penggantian dinas jaga pada setiap putaran dinas jaga laut dilaksanakan 
Tabel 7 Elemen kompetensi dan kriteria unjuk kerja dari unit kompetensi melakukan penangkapan ikan di laut dengan menggunakan rawai tuna (longline) Kode Unit A.031110.013.01

\begin{tabular}{|c|c|c|}
\hline & Elemen kompetensi & Kriteria unjuk kerja \\
\hline 1. & $\begin{array}{l}\text { Menentukan haluan dan } \\
\text { posisi setting }\end{array}$ & $\begin{array}{l}\text { 1.1 Arah dan kekuatan angin diukur } \\
\text { 1.2 Haluan dan posisi setting ditentukan }\end{array}$ \\
\hline 2. & $\begin{array}{l}\text { Menentukan kedalaman } \\
\text { pancing }\end{array}$ & $\begin{array}{l}\text { 2.1 Kedalaman swimming layer ikan diprediksi } \\
\text { 2.2 Arah dan kekuatan arus diukur } \\
\text { 2.3 Kedalaman pancing ditentukan }\end{array}$ \\
\hline 3. & $\begin{array}{l}\text { Malakukan persiapan } \\
\text { umpan, alat dan } \\
\text { perlengkapan }\end{array}$ & $\begin{array}{l}\text { 3.1 Ikan umpan disiapkan } \\
\text { 3.2 Alat dan perlengkapan rawai tuna disiapkan } \\
\text { 3.3 Alat dan perlengkapan setting disiapkan }\end{array}$ \\
\hline 4 & $\begin{array}{l}\text { Menurunkan rawai tuna } \\
\text { (setting) }\end{array}$ & $\begin{array}{l}\text { 4.1 Bendera utama, radio bouy, light bouy, dirangkai } \\
\text { 4.2 Penempatan petugas setting pada posisinya dilakukan } \\
\text { 4.3 Setting rawai tuna dilakukan }\end{array}$ \\
\hline 5 & $\begin{array}{l}\text { Menghanyutkan rawai } \\
\text { tuna (drifting) }\end{array}$ & $\begin{array}{l}\text { 5.1 Peralatan dan perlengkapan setting disimpan } \\
\text { 5.2 Perlengkapan dan peralatan untuk hauling disiapkan } \\
\text { 5.3 Posisi kapal, pancing dan kondisi cuaca diukur menggunakan } \\
\text { peralatan deteksi navigasi }\end{array}$ \\
\hline 6 & $\begin{array}{l}\text { Menaikkan, mengambil } \\
\text { ikan hasil tangkapan } \\
\text { dan menyusun kembali } \\
\text { rawai tuna (hauling) }\end{array}$ & $\begin{array}{l}\text { 6.1 Penempatan petugas hauling pada posisinya } \\
\text { dilakukan } \\
\text { 6.2 Proses hauling dan pengambilan hasil tangkapan } \\
\text { dilakukan } \\
\text { 6.3 Data hauling dicatat }\end{array}$ \\
\hline & Menata alat & $\begin{array}{l}\text { 7.1 Rawai tuna dan perlengkapannya dirapihkan } \\
\text { 7.2 Geladak kerja dibersihkan } \\
\text { 7.3 Peralatan pendukung operasi rawai tuna dimatikan }\end{array}$ \\
\hline
\end{tabular}

Tabel 8 Nilai kesenjangan elemen kompetensi nahkoda kapal longline di PPN Palabuhanratu

\begin{tabular}{|c|c|c|c|c|}
\hline No & Elemen kompetensi & $\mathrm{CL}_{\mathrm{R}}$ & $\mathrm{CL}_{\mathrm{c}}$ & Gap \\
\hline 1. Mere & ncanakan operasi penangkapan ikan & & & \\
\hline a & $\begin{array}{l}\text { Menentukan jenis ikan sasaran, alat penangkap ikan dan } \\
\text { daerah penangkapan ikan }\end{array}$ & 1 & 1 & 0 \\
\hline $\mathrm{b}$ & Memprakirakan cuaca & 1 & 1 & 0 \\
\hline c & Menghitung waktu operasi dan kebutuhan operasi & 1 & 0,98 & 0,02 \\
\hline$d$ & Mendokumentasikan rencana operasi penangkapan & 1 & 0,55 & 0,45 \\
\hline 2. Men & iapkan kelaiklautan kapal & & & \\
\hline a & Melengkapi dokumen kapal & 1 & 0,08 & 0,92 \\
\hline $\mathrm{b}$ & $\begin{array}{l}\text { Melengkapi jumlah awak kapal sesuai kualifikasi dan } \\
\text { fungsinya }\end{array}$ & 1 & 1 & 0 \\
\hline c & Melengkapi perlengkapan keselamatan kapal dan manusia & 1 & 0,60 & 0,40 \\
\hline d & $\begin{array}{l}\text { Melaporkan keberangkatan kapal ke syahbandar perikanan } \\
\text { dan syahbandar umum }\end{array}$ & 1 & 0,70 & 0,30 \\
\hline 3. Men & iapkan kelaikan operasi penangkapan ikan & & & \\
\hline a & $\begin{array}{l}\text { Melengkapi dokumen perijinan yang terkait dengan usaha } \\
\text { penangkapan ikan }\end{array}$ & 1 & 0,10 & 0,90 \\
\hline b & Melengkapi kebutuhan perbekalan kapal dan awak kapal & 1 & 0,88 & 0,12 \\
\hline c & Menyiapkan alat dan perlengkapan penangkap ikan & 1 & 1 & 0 \\
\hline 4. Mela & ssanakan dinas jaga laut & & & \\
\hline a & Menyiapkan perlengkapan dinas jaga laut & 1 & 1 & 0 \\
\hline $\mathrm{b}$ & Memantau rute, pengendalian kapal dan keamanan berlayar & 1 & 0,76 & 0,24 \\
\hline$\overline{5 . \text { Mela }}$ & kukan penangkapan ikan di laut dengan menggunakan rawai & & & \\
\hline a & Menentukan haluan dan posisi setting & 1 & 0,45 & 0,55 \\
\hline b & Menentukan kedalaman pancing & 1 & 0,83 & 0,17 \\
\hline c & Melakukan persiapan ikan umpan, alat dan perlengkapan & 1 & 1 & 0 \\
\hline$d$ & Menurunkan rawai tuna (setting) & 1 & 1 & 0 \\
\hline e & Menghanyutkan rawai tuna (drifting) & 1 & 1 & 0 \\
\hline f & & 1 & 1 & 0 \\
\hline & $\begin{array}{l}\text { Menalkkan, mengambll Ikan hasIl tangkapan dan menyusun } \\
\text { kembali rawai tuna (hauling) ikan hasil tangkapan }\end{array}$ & & & \\
\hline$g$ & Menata alat & 1 & 1 & 0 \\
\hline
\end{tabular}

Keterangan:

$\mathrm{CL}_{\mathrm{C}}$ : Current competency level

$\mathrm{CL}_{\mathrm{R}}$ : Required competency level 
Tabel 9 Capaian kompetensi nakhoda kapal rawai tuna di PPN Palabuhanratu

\begin{tabular}{llcccc}
\hline No & \multicolumn{1}{c}{ Unit kompetensi } & Total $\mathbf{C L}_{\mathbf{R}}$ & Total CL & Gap & $\begin{array}{l}\text { Kompetensi } \\
\text { tercapai (\%) }\end{array}$ \\
\hline 1 & $\begin{array}{l}\text { Merencanakan operasi } \\
\text { penangkapan ikan }\end{array}$ & 4 & 3,53 & 0,47 & 88 \\
\hline 2 & Menyiapkan kelaiklautan kapal & 4 & 2,38 & 1,62 & 59 \\
\hline 3 & $\begin{array}{l}\text { Menyiapkan kelaikan operasi } \\
\text { penangkapan ikan }\end{array}$ & 3 & 1,98 & 1,02 & 66 \\
\hline 4 & Melaksanakan tugas jaga laut & 2 & 1,76 & 0,24 & 88 \\
\hline 5 & $\begin{array}{l}\text { Melakukan penangkapan ikan di laut } \\
\text { dengan menggunakan rawai tuna }\end{array}$ & 7 & 6,28 & 0,72 & 90 \\
\hline & Rata-rata & & & \\
\hline
\end{tabular}

kualitas ikan tuna yang memenuhi standar mutu ekspor masih rendah (Nurani et al. 2013).

Nelayan dalam satu unit penangkapan ikan dengan longline di PPN Palabuhanratu meliputi beberapa kategori pekerjaan, diantaranya yaitu Nahkoda kapal (tekong), Wakil Nahkoda, Bosman, KKM, Koki, Prosesing, dan ABK. Masing-masing kategori pekerjaan membutuhkan pengetahuan dan keterampilan yang berbeda. Lampiran Keputusan Menteri Tenaga Kerja No. 298/2013, telah memberikan panduan yang jelas standar kompetensi kerja untuk bidang profesi penangkapan ikan. Dalam lampiran keputusan ini terdapat tiga jenjang kualifikasi untuk pekerjaan di bidang penangkapan ikan, yaitu Jenjang kualifikasi Sertifikat VI (enam), V (lima) dan III (tiga). Jenjang VI untuk profesi Nakhoda Kapal Ikan, jenjang $\mathrm{V}$ untuk Perwira Kapal dan jenjang III untuk ABK. Pekerjaan di kapal penangkap ikan tergolong pekerjaan yang membahayakan dibanding pekerjaan lain (Suwardjo et al. 2010). Hal ini menjadi penting untuk dapat menguasai kompetensi pekerjaan sesuai dengan jenjang kualifikasinya.

Berdasarkan hasil pengamatan di lapangan, Nakhoda kapal longline yang ada di PPN Palabuhanratu, selain mengerjakan pekerjaan yang ada pada unit kompetensi Nakhoda (Kode Unit A.031110.001.01, A.031110.002.01, A.031110.003.01), juga mengerjakan pekerjaan pada unit kompetensi Perwira Kapal (Kode Unit A.031110.004.01 dan A.031110.013.01).Unit kompetensi dengan Kode Unit A.031110.001. 01, memiliki 4 elemen kompetensi dengan 12 point kriteria unjuk kerja.Unit kompetensi dengan Kode Unit A.031110.002.01, memiliki 4 elemen kompetensi dengan 11 point kriteria unjuk kerja.Unit kompetensi dengan Kode Unit A.031110.003.01, memiliki 3 elemen kompetensi dengan 9 point kriteria unjuk kerja. Unit kompetensi dengan Kode Unit A.031110. 004.01, memiliki 2 elemen kompetensi dengan 19 point kriteria unjuk kerja. Unit kompetensi dengan Kode Unit A.031110.013.01, memiliki 7 elemen kompetensi dengan 20 point kriteria unjuk kerja.
Standar pekerjaan dari seorang nakhoda kapal penangkap ikan telah dideskripsikan dengan sangat jelas dalam SKKNI. Nahkoda memiliki 5 unit standar kompetensi, yaitu: 1) Merencanakan operasi penangkapan ikan, 2) Menyiapkan kelaiklautan kapal, 3) Menyiapkan kelaikan operasi penangkapan ikan, 4) Melaksanakan dinas jaga laut, dan 5) Melakukan penangkapan ikan di laut dengan menggunakan rawai tuna. Nakhoda pada perikanan longline memiliki peran yang sangat penting untuk keberhasilan usaha ini. Hal ini seperti dinyatakan oleh Nurani et al. (2008), kebutuhan SDM yang terampil dan handal merupakan faktor yang perlu diperhatikan untuk pengembangan perikanan tuna di Selatan Jawa. Sementara itu Retnowati (2014) juga menyatakan SDM Nelayan merupakan faktor penyebab menurunnya ekspor layur dari PPN Palabuhanratu, dengan akar penyebab masalah adalah tingkat pendidikan yang masih rendah.

Hasil penelitian menyatakan masih adanya kesenjangan (gap) antara kompetensi yang dimiliki Nakhoda kapal longline di PPN Palabuhanratu jika dibandingkan dengan kompetensi yang ada dalam SKKNI. Kesenjangan sebagian besar terjadi pada elemen kompetensi yang ada pada jenjang VI, yaitu dari total 11 elemen kompetensi pada jenjang VI ini, ada 4 elemen kompetensi yang tercapai dan 7 elemen kompetensi belum tercapai. Sementara itu elemen kompetensi pada jenjang $\mathrm{V}$, sebagian besar telah tercapai yaitu 6 elemen kompetensi tercapai dan 3 elemen kompetensi belum tercapai.

Pada unit "Merencanakan operasi penangkapan", kesenjangan kompetensi terjadi pada elemen "menghitung waktu operasi dan kebutuhan operasi penangkapan ikan"; serta "mendokumentasikan rencana operasi penangkapan". Nilai gap terjadi karena seluruh kebutuhan perbekalan disiapkan oleh perusahaan. Penentuan lama operasi penangkapan tergantung bahan perbekalan yang dibawa dan tergantung permintaan perusahaan. Pihak perusahaan dapat sewaktu-waktu memanggil 
kapal untuk kembali ke pelabuhan jika harga ikan sedang baik. Kapal yang sedang beroperasi di laut harus segera pulang, jika tidak ada kapal pengangkut. Apabila ada kapal pengangkut, operasi bisa lebih lama karena ikan hasil tangkapan dapat dititipkan pada kapal pengangkut milik perusahaan.

Unit "Menyiapkan kelaikautan kapal" memiliki kesenjangan pada elemen kompetensi "melengkapi dokumen keberangkatan", "melengkapi perlengkapan keselamatan kapal dan manusia"; dan "melaporkan keberangkatan kapal ke syahbandar perikanan dan syahbandar umum". Nahkoda kapal longline di PPN Palabuhanratu tidak memiliki kompetensi tersebut, karena seluruh perijinan keberangkatan dan kedatangan telah dilakukan oleh pihak perusahaan. Tidak ada kesenjangan atau nilai gap 0 terdapat pada elemen "melengkapi jumlah awak kapal sesuai kualifikasi dan fungsinya", hal ini disebabkan ABK yang ikut beroperasi dipilih langsung oleh Nahkoda.

Unit "Menyiapkan kelaikan operasi penangkapan ikan" memiliki kesenjangan pada elemen "melengkapi dokumen perijinan yang terkait dengan usaha penangkapan ikan'. Hal ini disebabkan nahkoda tidak mengetahui proses perijinan terkait usaha penangkapan. Elemen kompetensi "melengkapi kebutuhan perbekalan kapal dan awak kapal" memiliki nilai gap yang tidak terlalu besar. Hal tersebut disebabkan nahkoda dapat menyiapkan dan mengestimasi kebutuhan, akan tetapi sisa kebutuhan tidak dilaporkan kepada perusahaan ataupun syahbandar perikanan.

Unit "Melaksanakan tugas jaga laut" memiliki nilai kesenjangan pada elemen kompetensi "memantau rute, pengendalian kapal dan keamanan berlayar".Pada elemen kompetensi ini, nahkoda kurang mengerti tentang peraturan pelayaran dan keselamatan di laut, selain itu catatan navigasi misalnya terkait dengan posisi haluan saat operasi penangkapan berlangsung juga tidak tercatat. Adapun pada elemen menyiapkan peralatan tugas jaga laut, tidak ada nilai kesenjangan. Nahkoda telah memiliki keahlian untuk menggunakan alat navigasi yaitu Global Positioning System (GPS) yang telah dilengkapi untuk membuat jalur pelayaran menuju daerah penangkapan ikan.

Pada unit "Melakukan penangkapan ikan di laut dengan menggunakan rawai tuna", terdapat dua elemen kompetensi yang memiliki gap, yaitu elemen "menentukan haluan dan posisi setting" dan "menentukan kedalaman pancing". Kedua elemen tersebut memiliki gap, karena sebagian nahkoda hanya memper- kirakan posisi setting dengan cara mencoba pada setting pertama. Apabila pada setting pertama tidak berhasil menangkap ikan, maka akan mencari posisi setting lain. Pengetahuan daerah penangkapan ikan yang potensial hanya berdasarkan pengalaman saja, tidak ada teknologi yang digunakan dalam penentuan posisi setting.

Keseluruhan kompetensi nahkoda kapal longline yang dimiliki saat ini sudah memenuhi $50 \%$ dari elemen kompetensi yang harus dikuasai. Sebagian besar elemen kompetensi yang dikuasai adalah pada jenjang $\mathrm{V}$ yaitu untuk kompetensi Perwira kapal. Pada jenjang VI yaitu untuk kompetensi nakhoda kapal penangkap ikan, sebagian besar elemen kompetensi tidak dikuasai. Hal ini disebabkan elemen kompetensi yang ada pada jenjang VI ini tidak dipercayakan ke nakhoda kapal, melainkan telah dilakukan sendiri oleh pihak perusahaan. Nahkoda tidak melakukan pengurusan dokumen yang diperlukan, seperti Surat Persetujuan Berlayar (SPB), Surat Ukur Kapal, Surat Tanda Pendaftaran Kapal (Certificate of Tonnage and Measurement), Surat Kebangsaan Kapal, Sertifikat garis muat kapal (Load Line Certificate) dan sertifikat hapus tikus (Derating certificate). Sesuai ketentuan SKKNI, pekerjaan nakhoda kapal adalah setara dengan jenjang VI KKNI, maka diperlukan upaya untuk mensosialisasikan ketentuan ini kepada pengusaha-pengusaha perikanan tuna longline.

Lincoln et al. (2002) menyatakan bahwa, keselamatan kapal penangkap ikan merupakan interaksi faktor-faktor yang kompleks, yakni human factor (Nakhoda dan ABK), machines (kapal dan peralatan keselamatan) dan enviromental (cuaca dan skim pengelolaan sumberdaya perikanan). Permasalahan keselamatan atau kecelakaan akan timbul apabila minimum satu elemen dari human factor, machines atau enviromental factor tersebut tidak berfungsi. Oleh karena itu keselamatan kapal ikan sangat perlu untuk diperhatikan. Hal tersebut sesuai dengan unit kompetensi "Menyiapkan kelaiklautan kapal" pada elemen kompetensi "melengkapi perlengkapan keselamatan kapal dan manusia". Pada elemen ini, kompetensi nahkoda perlu ditingkatkan. Mengingat pengetahuan tentang keselamatan kapal masih kurang. Kesenjangan kompetensi yang dimiliki nakhoda saat ini, disebabkan sebagain besar nakhoda mendapatkan pengetahuan dan keterampilan sebagai nakhoda adalah berdasarkan pencapaian pengetahuan dan pengalaman secara mandiri. Nakhoda kapal longline di PPN Palabuhanratu sebagian besar memiliki Surat Keterangan Kecakapan (SKK) 60 mil, 
sebagai syarat dapat menjadi nakhoda kapal. Berdasarkan peraturan Menteri Perhubungan No. KM 9 tahun 2005 tentang Pendidikan dan Pelatihan, Ujian serta Sertifikasi Pelaut Kapal Penangkap Ikan, sertifikat untuk nakhoda kapal mencakup Sertifikat Ahli Penangkapan Ikan Tingkat I (ANKAPIN I), ANKAPIN II dan ANKAPIN III. Mengacu kepada persyaratan yang ada untuk memiliki sertifikat tersebut, yaitu ANKAPIN I minimal D3 Program Studi Penangkapan Ikan, Sarjana Muda atau Sarjana Program Studi Penangkapan Ikan atau Pemanfaatan Sumberdaya Perikanan; ANKAPIN II minimal Sekolah Menengah Kejuruan (SMK) Bidang Studi Penangkapan Ikan, dan ANKAPIN III minimal Sekolah Dasar atau yang sederajat. Hasil penelitian ini menguatkan bahwa kompetensi yang dikuasai saat ini oleh nakhoda kapal longline di PPN Palabuhanratu setara jenjang $\mathrm{V}$ KKNI.

Kualitas sumberdaya manusia di bidang penangkapan ikan dapat ditingkatkan melalui standarisasi dan sertifikasi kompetensi. Sertifikasi kompetensi merupakan proses pemberian sertifikat kompetensi yang dilakukan secara sistematis dan obyektif melalui uji kompetensi sesuai SKKNI, standar internasional dan/atau standar khusus. Kompetensi adalah pengetahuan, keterampilan dan perilaku yang dibutuhkan seseorang untuk memenuhi perannya. Penilaian terhadap kompetensi, keterampilan dan kemampuan, serta mengetahui ciri-ciri kepribadian dan perilaku kunci individu akan memperbesar peluang memilih tim yang memiliki potensi untuk sukses (Shahhpsseini 2011). Nurmianto et al. (2006), menyebutkan bahwa kompetensi adalah bagian dalam dan selamanya ada pada kepribadian seseorang dan dapat memprediksikan tingkah laku dan performansi secara luas pada semua situasi dan job tasks. Ciri kompetensi adalah perilaku yang spesifik, dapat dilihat dan dapat diverifikasi; yang secara reliable dan logis dapat dikelompokkan bersama; serta sudah diidentifikasi sebagai hal-hal yang berpengaruh besar terhadap keberhasilan pekerjaan (Nurmianto et al. 2006).

\section{KESIMPULAN}

Standar Kompetensi Kerja Nasional Indonesia (SKKNI) untuk Nakhoda kapal longline telah dirumuskan dengan baik. Nahkoda memiliki 5 unit standar kompetensi, yaitu: 1) Merencanakan operasi penangkapan ikan, 2) Menyiapkan kelaiklautan kapal, 3) Menyiapkan kelaikan operasi penangkapan ikan, 4) Melaksanakan dinas jaga laut, dan 5) Melakukan penangkapan ikan di laut dengan menggunakan rawai tuna. Kelima unit kompetensi tersebut, mencakup 20 elemen kompetensi. Capaian dari setiap elemen kompetensi ditunjukkan oleh kriteria unjuk kerja.

Kompetensi Nakhoda kapal longline di PPN Palabuhanratu belum sesuai dengan SKKNI. Sebagian besar elemen kompetensi yang sudah tercapai adalah pada jenjang $\mathrm{V}$.

\section{SARAN}

Pemerintah perlu mensosialisasikan SKKNI di bidang penangkapan ikan kepada masyarakat, untuk dapat dipahami dan diimplementasikan dengan baik dalam kerangka meningkatkan daya saing SDM di bidang ini dengan diberlakukannnya MEA. Penguatan kompetensi Nakhoda kapal longline perlu dilakukan melalui sertifikasi kompetensi.

\section{DAFTAR PUSATAKA}

Ardani, Nurani TW, Lubis E. 2013. Integrasi Pasar Komoditas Unggulan Minapolitan di Palabuhanratu. Marine Fisheries. 4(1): 23-33.

Iskandar BH, Ghina AW, Tri WN. 2011. Pre Requisite Study On Application Of Hazard Analysis Critical Control Point Management System For On Board Tuna Longliner. Indonesian Fisheries Research Journal. 17(2):111-117.

[Kemnakertrans] Kementrian Tenaga Kerja dan Transmigrasi Republik Indonesia. 2013. Lampiran Keputusan Menteri Tenaga Kerja dan Transmigrasi Republik Indonesia Nomor 298 Tahun 2013 Tentang Penetapan Standar Kompetensi Kerja Nasional Indonesia Kategori Pertanian, Kehutanan dan Perikanan Golongan Pokok Perikanan Golongan Penangkapan Ikan Sub Golongan Penangkapan Ikan di Laut. Jakarta: (ID) Kemnakertrans.

Lincoln JM, Diana SH, George AC, Rachel P. 2002. Proceedings of the International Fishing Industry Safety and Health Conference. U.S. Department of Health and Human Services, Public Health Service, Center for Disease Control and Prevention, National Institute for Occupational Safety and Health, Occupational Health Program, Department of Environmental Health, Harvard School of Public Health. Massachusetts, U.S.A.

Nurani TW, Haluan J, Saad S, Lubis E. 
2008. Rekayasa Sistem Pengembangan Perikanan Tuna di Perairan Selatan Jawa. Jurnal Forum Pascasarjana. 31(2): 79-92.

Nurani TW, Haluan J, Saad S, Lubis E. 2010. Analysis of Fishing Port to Support the Development of Tuna Fisheries in the South Coast of Java. Indonesia Fisheries Research Journal. 16(2): 69-78.

Nurani TW, Haluan J, Saad S, Lubis E, Irnawati R. 2011. Development of Tuna Fisheries Management Strategies for the Southern Coast of Java: An Application of Interpretative Structural Modeling (ISM). Indonesia Fisheries Research Journal. 17(2): 101-110

Nurani TW, Wisudo SH, Imron M. 2012.Implementasi Manajemen Mutu pada Industri Penangkapan Ikan. Marine Fisheries. 3(2) 103-113.

Nurani TW, Murdaniel RPS, Harahap MH. 2013. Upaya Penanganan Mutu Ikan Tuna Segar Hasil Tangkapan Kapal Tuna Longline untuk Tujuan Ekspor. Marine Fisheries. 4(2): 153-162.

Nurmianto E, Siswanto N, Sapurwan S. 2006. Perancangan Penilaian Kinerja Karyawan Berdasarkan Kompetensi Spencer Dengan Metode Analytical Hierarchy Process (Studi Kasus di Sub Dinas Pengairan, Dinas Pekerjaan Umum, Kota Probolinggo). Surabaya: Jurnal Teknik Industri. 8(1): 40-53.

Palan R. 2007. Competency Management. Octa MJ, Penerjemah; Ramelan, editor. Jakar-ta (ID): Penerbit PPM. Terjemahan dari: Competency Management- $A$ Practicine's Guide.
Purwangka F, Wisudo SH, Iskandar $\mathrm{BH}$, Haluan J. 2013.Kebijakan Internasional Mengenai Keselamatan Nelayan. Buletin PSP. 21(1): 51-65.

Ramadhan MR, Yoanita Y, Sugih A. 2014. Analisis Beban Kerja dan Pengukuran Gap Kompetensi Teknisi Laboratorium Umum dan Fakultas Z Pts Xy :Reka Integra Jurnal Online Institut Teknologi Nasional. 2(3): 384-395.

Retnowati H, Sukmawati A, Nurani TW. 2014. Strategi Peningkatan Kinerja Nelayan dalam Rantai Pasok Ikan Layur melalui Pengembangan Modal Insani di Pelabuhanratu. Jurnal Manajemen Pengembangan Industri Kecil Menengah. 9(2): 140-149.

Shahhpsseini, V. 2011. Competency-Based Selection and Assignment of Human Resources to Construction Projects: Scientia Iranica A. 18(2): 163-180.

Susilo W, Eriyatno, Affandi J, Goenawan DA. 2011. Rancang Bangun Model Audit Manajemen Sumber Daya Manusia, Menggunakan Pendekatan Sistem. Jurnal Manajemen IKM. 6(2): 133-142.

Suwardjo D, Haluan J, Jaya I, Poernomo SH. 2010. Keselamatan Kapal Penangkap Ikan, Tinjauan dari Aspek Regulasi Nasional dan Internasional. Jurnal Teknologi Perikanan dan Kelautan. 1(1): 1-13. 